\section{CONCLUSION}

Modest improvements have occurred in some chemical levels for parameters of water quality in swimming pools. Since the introduction of the NSW Department of Health's Public Swimming and Spa Pool Guidelines 1996 greater emphasis has been placed on maintaining disinfection at a level that will assist in the removal of disease-causing organisms.

Pool operators not meeting requirements of the 1996 Guidelines were given on the spot advice to rectify problems identified in the survey. Failures in chemical levels for parameters alone do not necessarily mean a health risk to the public. Where failures were identified, additional factors were considered such as number of bathers, and type and method of disinfection. If the pool was assessed as a public health risk it would be closed until problems were rectified. In this survey, none of the pools required closure.

The Mid Western Public Health Unit will be working with pool operators during the 2001-2002 summer season to ensure that appropriate maintenance and monitoring occurs. With regard to chemical levels for parameters of water quality, an emphasis will be placed on chlorine and $\mathrm{pH}$ levels, as these are considered the greatest risk to public health if not maintained appropriately.

\section{REFERENCES}

1. Hoadley AW and Knight DE. External Otitis Among Swimmers and Nonswimmers. Archives of Environmental Health September 1975; 30: 445-448.

2. NSW Department of Health. Public Swimming and Spa Pool Guidelines 1996. Sydney: NSW Department of Health, 1996. State Health Publication No.(EHF\&B) 960106.

3. Southern Sydney Public Health Unit. Cryptosporidiosis Outbreak in Southern Sydney. Public Health Update February 1995; 2(2).

4. Palintest. The Palintest System-Test Instructions for Pooltest 25. Newcastle upon Tyne: Palintest Ltd, 1998.

5. Palintest. The Palintest System-Test Instructions for Photometer 5000 Pool Test Kit. Newcastle upon Tyne: Palintest Ltd, 1980.

6. Shaw N. Study of Public Swimming Pools and Spa Pools in NSW, 1993. NSW Public Health Bulletin 1994; 5(12): 131-133. 借

\title{
DEVELOPMENT OF A CHILD AND YOUTH HEALTH REPORT CARD FOR CENTRAL SYDNEY, 2000
}

\section{Belinda O'Sullivan \\ Public Health Officer Training Program \\ NSW Department of Health}

\section{Garth Alperstein and Ajsa Mahmic \\ Division of Population Health \\ Central Sydney Area Health Service}

This article describes how the first Child and Youth Report Card for the Central Sydney Area Health Service (CSAHS) was developed. The purpose of the Report Card is to contribute to the improvement of child and youth health outcomes through supporting service planning by providing regular information on the status of child and youth health in CSAHS to managers, planners, health professionals and other relevant stakeholders in child and youth health.

\section{BACKGROUND}

Over the past decade there has been an increased focus nationally and internationally on useful ways of monitoring child and youth health for the purpose of informing service planning. ${ }^{1-3}$ The emphasis is moving from using information that is available and easy to collect for routine reporting, to information that is more helpful to service planning and service delivery, and for monitoring health outcomes.

The Strategic Plan Health Gain for Children and Youth in Central Sydney marked a first attempt in the CSAHS to determine priority issues for children and youth. ${ }^{4}$ It used the Health Goals and Targets for Australian Children and Youth as a basis for the plan. 'High priority' health issues were ascertained by analysing information on:

- prevalence

- severity of a condition

- community concern for the issue

- efficacy of available interventions.

\section{METHODS}

To establish the Report Card, it was necessary to determine the information that would be useful to include. In order to build on the work undertaken for the Strategic Plan-and to improve our understanding of indicators-Mahmic, Alperstein and Ward undertook a survey of 36 national and international 'experts' in child and youth health (unpublished data). 'Experts' were health professionals who had expertise in both child health and public health. The response rate was 72 per cent (26 respondents).

A questionnaire requested the experts to rate the importance of monitoring 135 health, social and educational issues for the population as a whole and for the socioeconomically disadvantaged, and also to rate how frequently the data should be collected (annually or every five years, etc.). The list of 135 issues was developed from the Strategic Plan as well as from the national and international literature on the monitoring of child health and indicators. The responses were analysed for agreement by the experts at two levels of concordance- -75 per cent and 90 per 
TABLE 1 SUMMARY OF INDICATORS RATED AS ESSENTIAL TO COLLECT FOR THE WHOLE POPULATION, AND FOR THE SOCIOECONOMICALLY DISADVANTAGED, AT 75 PER CENT AGREEMENT

\begin{tabular}{|c|c|c|}
\hline Indicators & $\begin{array}{l}\text { Essential for the } \\
\text { population as a whole }\end{array}$ & $\begin{array}{l}\text { Essential for the } \\
\text { socioeconomically disadvantaged }\end{array}$ \\
\hline INFANTS (0-1 years) & No. (\%) & No. (\%) \\
\hline \multicolumn{3}{|l|}{ Mortality } \\
\hline Infant & $26(100)$ & $21(81)$ \\
\hline Perinatal & $25(96)$ & $21(81)$ \\
\hline Sudden Infant Death Syndrome & $25(96)$ & - \\
\hline Unintentional injury & $24(92)$ & $20(77)$ \\
\hline Drowning & $23(88)$ & - \\
\hline Traffic related & $23(88)$ & - \\
\hline \multicolumn{3}{|c|}{ Morbidity, Disability and Developmental } \\
\hline Physical abuse & $26(100)$ & $21(81)$ \\
\hline Pertussis cases & $25(96)$ & $20(77)$ \\
\hline Sexual abuse & $24(92)$ & - \\
\hline Birth defects (overall) & $24(92)$ & - \\
\hline Prematurity & $23(88)$ & $21(81)$ \\
\hline Unintentional injury & $23(88)$ & - \\
\hline Low birthweight & $23(88)$ & $23(88)$ \\
\hline Neural tube defects & $23(88)$ & - \\
\hline Measles & $23(88)$ & - \\
\hline Haemophilus influenza type B & $23(88)$ & - \\
\hline Traffic-related injuries & $22(85)$ & - \\
\hline Breastfeeding at three months & $22(85)$ & $20(77)$ \\
\hline Burns and scalds & $21(81)$ & - \\
\hline Congenital rubella & $21(81)$ & - \\
\hline Falls & $20(77)$ & - \\
\hline Neglect & $20(77)$ & - \\
\hline \multicolumn{3}{|l|}{ CHILDREN (1-9 years) } \\
\hline \multicolumn{3}{|l|}{ Mortality } \\
\hline Unintentional injury & $25(96)$ & $21(81)$ \\
\hline Poisoning & $25(96)$ & - \\
\hline Drowning & $24(92)$ & - \\
\hline Traffic related & $24(92)$ & $20(77)$ \\
\hline Falls & $22(85)$ & - \\
\hline \multicolumn{3}{|l|}{ Morbidity, Disability and Developmental } \\
\hline Physical abuse & $26(100)$ & $21(81)$ \\
\hline Sexual abuse & $25(96)$ & $20(77)$ \\
\hline Measles & $24(92)$ & $20(77)$ \\
\hline Pertussis & $24(92)$ & - \\
\hline Fully immunised at age two years & $24(92)$ & $20(77)$ \\
\hline Unintentional injury & $23(88)$ & - \\
\hline Fully immunised at school entry & $23(88)$ & $20(77)$ \\
\hline Traffic-related injuries & $22(85)$ & - \\
\hline Poisoning & $21(81)$ & - \\
\hline Disability (all cases) & $21(81)$ & - \\
\hline Burns and scalds & $20(77)$ & - \\
\hline Emotional abuse & $20(77)$ & - \\
\hline Neglect & $20(77)$ & - \\
\hline \multicolumn{3}{|l|}{ ADOLESCENTS (10-18 years) } \\
\hline \multicolumn{3}{|l|}{ Mortality } \\
\hline Unintentional injury & $26(100)$ & $20(77)$ \\
\hline Suicide & $26(100)$ & - \\
\hline Traffic related & $25(96)$ & $20(77)$ \\
\hline Poisoning & $23(88)$ & - \\
\hline \multicolumn{3}{|c|}{ Morbidity, Disability and Developmental } \\
\hline Unintentional injury (all cases) & $24(92)$ & - \\
\hline Tobacco consumption rates & $24(92)$ & $20(77)$ \\
\hline Alcohol consumption rates & $23(88)$ & - \\
\hline Sexually Transmitted Diseases & $23(88)$ & - \\
\hline HIV-AIDS & $23(88)$ & - \\
\hline Self-inflicted injuries & $22(85)$ & - \\
\hline Disability (all cases) & $22(85)$ & - \\
\hline Teenage births & $22(85)$ & - \\
\hline Physical abuse & $22(85)$ & - \\
\hline Sexual abuse & $22(85)$ & - \\
\hline Traffic-related injuries & $21(81)$ & - \\
\hline Other substance abuse & $20(77)$ & $20(77)$ \\
\hline \multicolumn{3}{|l|}{ SOCIAL AND EDUCATION } \\
\hline Families below poverty line & $24(92)$ & $23(88)$ \\
\hline High school retention rate & $24(92)$ & $24(92)$ \\
\hline Children in foster care & $23(88)$ & $21(81)$ \\
\hline Unemployment rate & $23(88)$ & $23(88)$ \\
\hline Youths in juvenile justice & $22(85)$ & $23(88)$ \\
\hline Overall homeless rate & $21(81)$ & - \\
\hline Youth homeless rate & $21(81)$ & $20(77)$ \\
\hline Family homeless rate & $20(77)$ & - \\
\hline
\end{tabular}




\section{TABLE 2}

\section{SUMMARY OF HEALTH STATUS OF CHILDREN AND YOUTH IN CSAHS COMPAREDTO NSW}

\begin{tabular}{|c|c|c|c|}
\hline Health goal or target & Rate compared to NSW & Rate compared to NSW & Rate compared to NSW \\
\hline $\begin{array}{l}\text { Reduce preventable } \\
\text { premature mortality }\end{array}$ & $\begin{array}{l}\text { Worse } \\
\mathscr{\partial} \mathscr{\partial} \mathscr{\partial} \\
\text { Perinatal mortality } \\
\text { Falls deaths } \\
\text { Poisoning deaths }\end{array}$ & $\begin{array}{l}\text { Similar } \\
\bigodot \bigodot \bigodot \\
\ominus\end{array}$ & 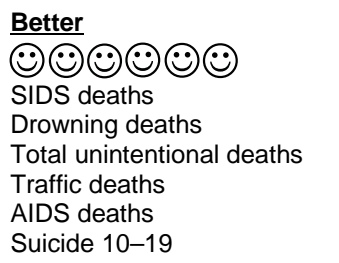 \\
\hline $\begin{array}{l}\text { Reduce the effect of } \\
\text { disability }\end{array}$ & $\begin{array}{l}\text { Worse } \\
\check{\mathscr{\sigma}} \\
\text { Asthma hospitalisations } \\
\text { Traffic-related injury }\end{array}$ & $\begin{array}{l}\text { Similar } \\
\bigodot \bigodot \\
\text { Low birth-weight }(-) \\
\text { Prematurity }(-)\end{array}$ & $\begin{array}{l}\text { Better } \\
\text { Neural tube defects } \\
\text { Neirth defects overall } \\
\text { Birt? } \\
\text { Drowning hospitalisations } \\
\text { Unintentional injury } \\
\quad \text { hospitalisations } \\
\text { Burns hospitalisations } \\
\text { Falls hospitalisations } \\
\text { Poisons hospitalisations } \\
\text { Sensorineural hearing loss }\end{array}$ \\
\hline $\begin{array}{l}\text { Reduce the effect of } \\
\text { vaccine-preventable } \\
\text { disease }\end{array}$ & Worse & $\begin{array}{l}\text { Similar } \\
\ominus \bigodot \bigodot \bigodot \\
\text { Measles }(+) \\
\text { Influenza type B }(+) \\
\text { Immunisation Coverage }(+)\end{array}$ & $\begin{array}{l}\text { Better } \\
\text { Pertussis }\end{array}$ \\
\hline $\begin{array}{l}\text { Reduce the effect of } \\
\text { conditions occurring in } \\
\text { adulthood that have their } \\
\text { origins in childhood or } \\
\text { adolescence }\end{array}$ & $\begin{array}{l}\text { Worse } \\
\ddot{\partial} \mathscr{\partial} \mathscr{\partial} \\
\text { Male smoking prevalence } \\
\text { Hepatitis C } 15-19 \text { years } \\
\text { Hepatitis B } 0-19 \text { years } \\
\text { Gonorrhoea } 0-19 \text { years }\end{array}$ & $\begin{array}{l}\text { Similar } \\
\odot \bigodot \bigodot \bigodot \\
\text { Dental disease }(-) \\
\text { Syphilis } 0-19 \text { years }(-) \\
\text { Breastfeeding at discharge from } \\
\text { hospital }(-)\end{array}$ & \begin{tabular}{l} 
Better \\
\hdashline$\bigodot \Theta$ \\
Maternal smoking in \\
$\quad$ pregnancy \\
Female smoking prevalence \\
AIDS
\end{tabular} \\
\hline $\begin{array}{l}\text { Enhance family and social } \\
\text { functioning }\end{array}$ & 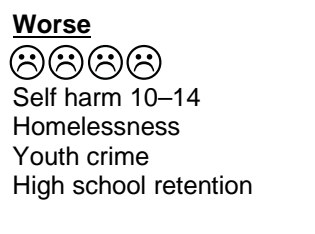 & 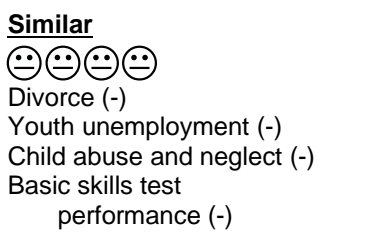 & 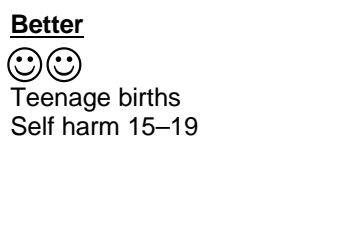 \\
\hline TOTAL SCORE & Worse $13 \ddot{\partial}$ & Similar $14 \bigodot$ & Better $20 \bigodot$ \\
\hline
\end{tabular}

cent. The results were collated using both the 75 per cent and 90 per cent levels of concordance that the information was important to collect for the population as a whole and the socioeconomically disadvantaged, and the 75 per cent level of concordance for how frequently the data should be collected.

The feasibility of collecting information from a range of sources was assessed by reviewing sources of health information and consulting with other sectors including housing, education, community services, juvenile justice, NSW Roads and Traffic Authority and Australian Hearing Services. Representatives from Aboriginal and some Non-English Speaking Background (NESB) groups in the health sector were also consulted to ascertain the importance and the cultural sensitivity of reporting certain types of information.
To establish ways that we could best present the information to suit a wide readership, we reviewed a range of local, national and international reports monitoring child health. ${ }^{1-3}$

Finally, a draft of a near complete version of the Report Card was evaluated using a semi-structured, qualitative, self-administered questionnaire. The questionnaire was distributed to local service planners and managers of the sectors involved. The questionnaire covered content, the format to be used for data presentation, and the potential use of the various sections of the Report Card.

\section{RESULTS}

At the 75 per cent level of agreement, 64 indicators were rated as essential to monitor for the population as a whole, and 25 indicator were rated as essential to monitor for the 
TABLE 3

TWO EXAMPLESTO ILLUSTRATE THE USE OF INDICATORS FOR TARGET SETTING AND SERVICE PLANNING

\begin{tabular}{|c|c|c|c|c|c|c|c|c|c|c|}
\hline $\begin{array}{l}\text { Health } \\
\text { Issue }\end{array}$ & Indicator & $\begin{array}{c}\text { Data } \\
\text { Source }\end{array}$ & $\begin{array}{l}\text { Current } \\
\text { Level } \\
\text { CSAHS }\end{array}$ & $\begin{array}{c}\text { Current } \\
\text { Level } \\
\text { NSW }\end{array}$ & $\begin{array}{l}\text { Current level } \\
\text { Aboriginal \& } \\
\text { Torres Strait } \\
\text { Islander }\end{array}$ & $\begin{array}{c}\text { Current level } \\
\text { OSB or LSAH } \\
\text { not English }\end{array}$ & $\begin{array}{c}\text { Target } \\
2003\end{array}$ & $\begin{array}{l}\text { Future } \\
\text { trend }\end{array}$ & $\begin{array}{l}\text { Past } \\
\text { trend }\end{array}$ & $\begin{array}{l}\text { Relevant } \\
\text { programs } \\
\text { required }\end{array}$ \\
\hline \multicolumn{11}{|l|}{ Antenatal } \\
\hline $\begin{array}{l}\text { Maternal } \\
\text { smoking } \\
\text { in } \\
\text { preg- } \\
\text { nancy } \\
\text { rate }\end{array}$ & $\begin{array}{l}\% \\
\text { mothers } \\
\text { that } \\
\text { smoked } \\
\text { during } \\
\text { preg- } \\
\text { nancy }\end{array}$ & $\begin{array}{l}\text { MDC } \\
\text { (HOIST) } \\
\text { Epidemiol- } \\
\text { ogy and } \\
\text { Surveil- } \\
\text { lance } \\
\text { Branch, } \\
\text { NSW Dept. } \\
\text { of Health }\end{array}$ & $\begin{array}{l}(1998) \\
N=591 \\
8.9 \%\end{array}$ & $\begin{array}{l}N=16881 \\
19.7 \%\end{array}$ & $\begin{array}{l}N(5 y)=204 \\
53.4 \%\end{array}$ & $\begin{array}{l}\text { Overseas } \\
\text { born } \\
N(5 y)=975 \\
6.1 \%\end{array}$ & & & & \\
\hline \multicolumn{11}{|c|}{ Youth-Workforce } \\
\hline $\begin{array}{l}\text { Traffic- } \\
\text { related } \\
\text { injuries }\end{array}$ & $\begin{array}{l}\text { Rate of } \\
\text { traffic- } \\
\text { related } \\
\text { injury by } \\
\text { age } \\
\text { group (0- } \\
20 \text { years) } \\
\text { (and road } \\
\text { user type) } \\
\text { and } n \text { per } \\
\text { year }\end{array}$ & $\begin{array}{l}\text { NSW } \\
\text { Provisional } \\
\text { Road } \\
\text { Traffic } \\
\text { Accident } \\
\text { Database, } \\
\text { Road and } \\
\text { Traffic } \\
\text { Authority, } \\
\text { NSW }\end{array}$ & $\begin{array}{l}(1998) \\
N=479 \\
43.2 / \\
10000\end{array}$ & $\begin{array}{l}N=6362 \\
35.6 / \\
10000\end{array}$ & & & & & & \\
\hline
\end{tabular}

socioeconomically disadvantaged group (Table 1). At the 90 per cent level of agreement, experts rated 24 indicators as essential to monitor for the population as a whole, compared with only one indicator for the socioeconomically disadvantaged group-high school retention rate (Table 1). In relation to periodicity of data collection at the 75 per cent level of concordance, annual collection was nominated for nearly all of the indicators except breast feeding at three months where only 46 per cent supported collecting this information.

The following criteria were used to discern what was included on the Report Card:

- 75 per cent agreement by experts that the issue was important to collect for the general population;

- 'high priority' issues from the CSAHS 'Strategic Plan';

- state or national child health priorities;

- issues where recent developments had changed the opportunity for health gain (for example, where new technology has improved early detection for congenital sensorineural hearing loss).

We divided the Report Card into three sections, using the framework of the Health Goals and Targets for Australian Children and Youth:

- Section One included a comparison of the health status of children and youth in CSAHS with NSW using the Health Goals and Targets for Australian Children and Youth framework (Table 2).
- Section Two included graphs and tables of the health and social issues, presented by life stage: that is, antenatal, birth, pre-school, primary school to youth-workforce, comparing CSAHS and NSW.

- Section Three (Table 3) presented indicators in the life stage format and in such a manner as to facilitate target setting and service planning.

Information was presented on sub-populations of Aboriginal and Torres Strait Islander, and some ethnic groups, and by local government authority (LGA) where possible, depending on the availability of information and the population numbers. Where numerator data were small, we presented five-year mean rates.

The Report Card described the intended periodicity of data collection (Table 4). Approximately half the indicators could be collected annually, since they were part of regular statewide data collections. However, about 20 per cent of the indicators will be available through the NSW Child Health Survey. Approximately 30 per cent of indicators would only be available by initiating specific research or surveillance (Table 4).

There was a sixty per cent (19 of 32 ) response rate for the evaluation survey. Seventeen respondents were from the health sector. Several managers commented positively on the Report Card as a 'great reference document', providing an 'overview of youth issues', established 'a baseline of health status from which to measure improvements' and as a document 'useful in 


\section{TABLE 4}

\section{PERIODICITY OF COLLECTION AND PUBLICATION OF DATA BY HEALTH ISSUE}

\begin{tabular}{|c|c|c|c|}
\hline Health Issues & Annually & About every five years & Child Health Survey \\
\hline \multicolumn{4}{|l|}{ Antenatal } \\
\hline \multicolumn{4}{|l|}{ Birth } \\
\hline Low birthweight & $\checkmark$ & & \\
\hline Prematurity & $\boldsymbol{v}$ & & \\
\hline Perinatal mortality & $v$ & & \\
\hline Infant mortality & $\boldsymbol{v}$ & & \\
\hline SIDS behaviours & & & $\boldsymbol{v}$ \\
\hline SIDS rate & $\boldsymbol{v}$ & & \\
\hline Neural tube defects & & $\boldsymbol{v}$ & \\
\hline Birth defects (overall) & $\boldsymbol{v}$ & & \\
\hline Breastfeeding & $\checkmark$ & & $\checkmark$ \\
\hline Exposure to smoking at home & & & $\boldsymbol{v}$ \\
\hline \multicolumn{4}{|l|}{ Early childhood-pre-school } \\
\hline Sensorineural hearing loss & $\boldsymbol{v}$ & & \\
\hline Measles & $\boldsymbol{v}$ & & \\
\hline Pertussis & $\boldsymbol{v}$ & & \\
\hline Influenza type B & $\boldsymbol{v}$ & & \\
\hline Immunisation Coverage & $\boldsymbol{v}$ & & \\
\hline Drowning & & $\boldsymbol{v}$ & \\
\hline Asthma & $\boldsymbol{v}$ & & \\
\hline Inactivity & & $\boldsymbol{v}$ & \\
\hline \multicolumn{4}{|l|}{ Primary School } \\
\hline Immunisation coverage & $\boldsymbol{v}$ & & \\
\hline Emotional-behavioural problems & & & $\boldsymbol{v}$ \\
\hline Dental disease & $\boldsymbol{v}$ & & \\
\hline Unintentional injury & $\boldsymbol{v}$ & & \\
\hline Burns & & $\boldsymbol{v}$ & \\
\hline Falls & & $\boldsymbol{v}$ & \\
\hline Poisoning & & $\boldsymbol{v}$ & \\
\hline Exposure to harmful ultraviolet light & & & $\boldsymbol{v}$ \\
\hline \multicolumn{4}{|l|}{ Youth-Workforce } \\
\hline Traffic-related injury & $\boldsymbol{V}$ & & \\
\hline Tobacco consumption & & $\boldsymbol{v}$ & \\
\hline Hazardous alcohol use & & $\boldsymbol{\nu}$ & \\
\hline Regular condom use & & $\boldsymbol{v}$ & \\
\hline Teenage births & $\boldsymbol{v}$ & & \\
\hline AIDS & $v$ & & \\
\hline Hepatitis C & & $\boldsymbol{v}$ & \\
\hline Hepatitis B & & $\checkmark$ & \\
\hline Syphilis & & $\boldsymbol{V}$ & \\
\hline Gonorrhoea & & $\boldsymbol{v}$ & \\
\hline Depression & & & $\checkmark$ \\
\hline Self harm & $\boldsymbol{v}$ & & \\
\hline Suicide & & $\boldsymbol{V}$ & \\
\hline \multicolumn{4}{|c|}{ SOCIAL, EDUCATIONAL AND ECONOMIC ISSUES } \\
\hline \multicolumn{4}{|l|}{ Whole of life } \\
\hline Home ownership by family type & & $\boldsymbol{v}$ & \\
\hline Overcrowded housing (public) & $\boldsymbol{v}$ & & \\
\hline Domestic violence rates & $\boldsymbol{v}$ & & \\
\hline Social support & & & $\checkmark$ \\
\hline Social capital & & & $\boldsymbol{v}$ \\
\hline \multicolumn{4}{|l|}{ Birth-Preschool-Early childhood } \\
\hline Divorce & & $\boldsymbol{V}$ & \\
\hline Child abuse or neglect & $\boldsymbol{v}$ & & \\
\hline Types of out of home care placements & $\boldsymbol{v}$ & & \\
\hline Number placed in out of home care & $\boldsymbol{v}$ & & \\
\hline Attendance pre-school-child care & & $\boldsymbol{v}$ & \\
\hline \multicolumn{4}{|l|}{ Primary School } \\
\hline Basic skills levels & $\boldsymbol{v}$ & & \\
\hline Absence levels & $\boldsymbol{v}$ & & \\
\hline English language proficiency by ethnicity & & $\boldsymbol{v}$ & \\
\hline \multicolumn{4}{|l|}{ Youth-workforce } \\
\hline High school retention & $\boldsymbol{v}$ & & \\
\hline Post compulsory school age transition & $\boldsymbol{v}$ & & \\
\hline Homelessness & $\boldsymbol{v}$ & & \\
\hline Youth labour force status & & $\checkmark$ & \\
\hline Youth occupational profile & & $\boldsymbol{v}$ & \\
\hline Youth unemployment & & $\boldsymbol{v}$ & \\
\hline Youth crime & $\boldsymbol{v}$ & & \\
\hline
\end{tabular}


planning service delivery'. They found the most useful section to be Section 2. Suggested changes were to provide more breakdown of information by subgroups and regions, and to invest in ways to make the Report Card more user friendly, such as providing summaries of each section. Recommended indicators to include in future Report Cards included social capital, local data collections and service delivery data. Changes were made where possible to improve the presentation of the Report Card and to investigate other information sources. Recommendations for future Report Cards were developed.

\section{DISCUSSION}

The issues that were selected for inclusion in the Report Card represent a combination of a comprehensive view of child and youth population health, opportunities for health gain, child health priorities, expert opinion and relevance to service planning.

Overall, the unpublished research by Mahmic, Alperstein and Ward revealed an unexpected disparity between expert ratings of indicators as essential to monitor for the general population, compared to the low socioeconomic sub-group. The method used to ascertain expert opinion meant that experts relied more on personal opinion rather than published literature to rate important indicators. Some experts commented that they did not rate indicators for the low socioeconomic subgroup highly because they were aware that these data were not available in Australia. It is for this reason that we were unable to report health issues by socioeconomic status.

The feasibility of collecting population-based information for some selected health and social issues, such as mental health and homelessness was poor. The main barrier to accessing important information in the health sector was lack of available information, whereas in the case of other sectors, a range of barriers emerged, including:

- limited resources;

- timeliness of our request in relation to their work agenda;
- privacy of information;

- lack of reliable information on people 0-20 years at the area health service level.

Managers and planners from other sectors and non-health organisations were very positive about collating information from multiple sources onto one monitoring system. However, it was difficult to manage data collection from the wide range of organisations, due to data availability, data aggregation and the need to contact a range of people within the same organisation to negotiate release of data.

It is expected that as more population-based child health information becomes available through improved monitoring and stronger ties with other sectors, a range of currently unreported indicators can be presented.

\section{CONCLUSION}

This was the first Child and Youth Report Card for CSAHS. As such, it will be refined and modified over time. The development of the Report Card was a valuable exercise, which not only brought together a range of previously unrelated information sources into the one report, but also has the potential to reinforce the process of evidencebased planning of child and youth health services in CSAHS, and improved inter-agency collaboration.

\section{REFERENCES}

1. Lazarus W and Gonzalez M. The state of our children, where we stand \& where we go from here. Oakland, California: Children Now, 1989.

2. Sullivan EA, Hogan A, Mohsin M et al. Health of children in South Western Sydney. Sydney: Epidemiology Unit, South Western Sydney Area Health Service, 1997. ISBN 1875909397.

3. Moon L, Rahman N and Bhatia K. Australia's Children: their health and wellbeing 1998. Canberra: AIHW, 1998. AIHW Catalogue no. PHE7.

4. Alperstein G, Thomson J and Crawford J. Strategic Plan: Health Gain for Children and Youth of Central Sydney. Sydney: Health Services Planning Unit and Division of Population Health, Central Sydney Area Health Service, 1997.

5. Project Report. Health Goals and Targets of Australian Children and Youth. Canberra: Department of Health, Housing and Community Services, 1992. 